\title{
Leadership Characteristic in the County Decentralization Era
}

\author{
$1^{\text {st }}$ Weni Rosdiana \\ Department of Public Administration \\ Faculty of Social Sciences and Law, \\ Universitas Negeri Surabaya \\ Surabaya, Indonesia \\ wenirosdiana@unesa.ac.id
}

\author{
$2^{\text {nd }}$ Yuni Lestari \\ Department of Public Administration \\ Faculty of Social Sciences and Law, \\ Universitas Negeri Surabaya \\ Surabaya, Indonesia \\ wenirosdiana@unesa.ac.id
}

\author{
$3^{\text {rd }}$ Muh Darwis \\ Public Administration Department \\ Universitas Negeri Makassar \\ Makassar, Indonesia \\ muh.darwis@unm.ac.id
}

$4^{\text {th }}$ Jetty Erna Hilda Mokat

State Administration Studies Program

Faculty of Social Sciences, Universitas

Negeri Manado

Manado, Indonesia

jettymokat@yahoo.co.id

\begin{abstract}
Counties requires an appropriate figurehead so capable of running its role effectively. A different situation demanding flexibility leadership.This paper aims to describe the concept idea of figurehead in an era of county decentralized. The concept of leaders figure that is characteristic of the village chief formulated taking into account the task of the village chief in the era of decentralization which includes governance, development and empowerment. The leader role in the decentralization era is different than any previous era. The county leadership of during this is more the role of routine tasks in running the Government from the task of development. Then it will be adopting the model of effective leadership of the American Management Association (AMA) which includes; strategic competence, performance competence, inspirational competence and character competence to motivate staff and community to enhance the potential for growth and development.
\end{abstract}

\section{Keywords - leadership, county decentralization}

\section{INTRODUCTION}

The role of leaders in guiding the organization should be done effectively. Leadership behavior can be associated with goal of the organization purpose. Conduct an effective leader in a time of leadership would not necessarily be effective also in the time of the other leadership. The characteristics of the leader figure need to be formulated taking into account the demands of a county decentralized era. The leadership has been recognized as an important focus in the field of organizational behavior who is one of the dynamic effects during the interaction of individuals and organizations. Leadership is no doubt has a major role in the achievement of outcomes. Different situations are demanding flexibility leadership.
In the development process, the leader role in the decentralization era is different than any previous era. The county leadership of during this is more the role of routine tasks in running the Government from the task of development. In order to achieve the purpose of the policy setting, then the village requires leaders who have the exact figure, so it's able to run its role effectively. This paper aims to describe the concept of effective leadership figure in county decentralization era.

The leadership has been recognized as an important focus in the field of organizational behavior where it is one of dynamics effects during individual interaction and organizations [1]. The leadership has a major role in the results of each project where all identifiable leadership style has variable results under different circumstances [2]. Fry explains that leadership plays a strategic tool to motivate staff to enhance the potential for growth and development [3].

A leader of the role and function are task function maintenance. The function of the task include; creating activities, looking for information, giving information, giving opinions, clarifying, coordinating, summarizing the eligibility, testing, evaluating and diagnosing. As for the function maintenance of a leader are as follows; zeal, set the standard, follow, expressing feelings, taking the consensus, creating harmony and reducing tensions [4].

American Management Association (AMA) mentions the core competencies of an effective Chief Executive is as follows [5].

\section{A. Strategic competence : Leading Among Integrity}

Thinking, planning and recognizing analytical and intuitive with the behavior characteristic as follows: 
- Creating a clear vision of what will be achieved.

- Developing a strategy and a plan.

- Using imaginative intuition.

- Understanding today in terms of the high illustration and identify trends.

- Balancing short with long term.

- Was it logical and full planning.

- What it open minded and receptive to new ideas.

- Handling complex problems creatively.

- What is decisive, but flexibility

B. Performance management competencies; Hand-Set lead

Handling an organization or effort an effective team to achieve the desired results with the behavior as follows:

- Deciding a clear direction and goals that are challenging.

- Establishing roles and responsibilities.

- Adjusting style to individuals and situations.

- The coach, empowering and delegates where it is appropriate.

- Giving compliments that timely and appropriate corrective feedback.

- Recognizing the people and giving them a reward for their achievements and improve your face.

- Poor performance; discipline when necessary.

- Addressing the crisis; identify and resolve conflicts.

- Is it for organizations and supporters or team-work.

- Building a cohesive team of people working together toward a common goal.

- Leading the change, bringing people together, overcoming resistance

C. The competence of the inspirational: Leading with Heart.

Demanding, energizing and empowering others to strive reaching a goal together through the effective communication of the vision, commitment to values indicated and use of the positive power and influence, with the following characteristics;

- Communicating the vision that inspired the interest.

- Increasing openness, wideband, interactive communication.

- Understanding other people, their values, aspirations, needs and desires, and corresponding message of the value.

- Revealing self-confident and assertive but not aggressive.

- Influence through the use of positive power and influence to use negotiation, engagement, direction and example.

- Using the bulk of power with restraint and wise-but quickly and surely when needed.

- Fulfill the security, social status and needs of others.

- Giving meaning to people and inspire enthusiasm about the idea and the efforts.
- Establishing a culture of high achievement in which the job is fraught with significance, interesting and challenging.

\section{Competency: Lead Character Through The Trust}

Do it yourself in a way that is ethically responsible that get a trust. The feature of such behaviors as follows:

- Acts ethically, with integrity.

- Upholding the values and principles that create a climate of trust and integrity.

- Showing the courage to take difficult decisions in line with the principles.

- Keeping the appointment.

- Approving the accountability over its own actions and those of the followers.

- Setting an example worthy to others

Thus the aspect of the AMA Leadership Models above includes;

1) Leadership with the head' that is doing the right thing. Reason and intuition create organizational effectiveness through the findings and cultural

2) Leadership with Legs' that is getting administrative things done.

3) Leadership By Hand' that is doing the right thing. Generates an efficient performance in certain situations.

4) Leadership Inspirational leadership with the heart 'that is directional actions. Stimulating to do inspiration in others through a change.

\section{RESEARCH METHOD}

This research is a descriptive study to analyze the leaders characteristics in a county decentralized era. The analysis was preceded by studies on a number of related literature is the literature of a number of studies can support analysis, include: the study of legislation, regulation, leadership style as well as the behavior of the leader. The source of the study is a reference book, the provisions of the legislation and related regulations, the published scientific journals, and references on Web sites that are accessed via the internet.

\section{RESULT AND DISCUSSION}

The district head is in charge of organizing the Government undertakes the development of the village, the village, the construction of the Village Community, and village community empowerment. The district head has authorities as follows:

- Leading organization of the County Government;

- Appoint and dismiss Councilor;

- Holding power financial management and village assets;

- $\quad$ Setting the rules of the village;

- $\quad$ Setting the APB Village;

- $\quad$ Guiding village community life;

- Guiding peace and order the community;

- Developing and improving the village economy as well as integrating it in order to achieve the 
economy scale is the most productive for the community prosperity of the village;

- Developing sources of village income;

- Proposing and receiving granting of most county's asset to enhance the well-being of community;

- Developing socio-cultural life of the village community;

- Utilizing appropriate technology;

- Coordinating the village development are participatory;

- Representing the village in and out of court or appointment to represent them in accordance with the legislation provisions; and

- Carrying out other authorized in accordance with the legislation provisions.

Empowerment of the villages conducted by:

1) Encouraging community participation in the planning and construction of the village which was carried out together with community;

2) Developing programs and Village development activities continuity by utilizing human resources and natural resources in the village;

3) Crafting Village development planning in accordance with the priorities, potential, and the value of local wisdom; compile a planning and budgeting in favor to the interests of citizens and the poor citizens of disability, women, children and marginal groups;

4) Developing a system of transparency and accountability in conducting village Government and the village construction;

5) Leverage existing civic institutions and institutions of Indigenous Village;

6) Encouraging public participation in the policy formulation of the village through Village deliberations;

7) Organized to improve the quality and capacity of the human resources community;

8) Implementing the mentoring Community Sustainable Village; and

9) Conducting surveillance and monitoring of the Village Government implementation and the development participatory Village by the community.

The duties and functions of the district head as the above will be done properly when the leader able to lead effectively. As stated in research Harwini showed that the attitude of servant leaders who are willing to serve the employees voluntarily, constantly and internalized in the organization as a value can understand that must drive culture and empower employees behavior [6]. Russel and Stone has been shown to affect the culture of the Organization's understanding of cooperatives [6].

Many other studies conducted to assess the relationship between organizational commitment and performance of employees [7]. Similar relationships have also been suggested between Organizational Citizenship Behavior (OCB) and the performance of employees [8][6]. OCB improves the performance of the staff [9]. Organizational commitment is one of the important factors that contribute to push the OCB [10][11]. Servant leadership is even desperately needed by the Organization to maximize the Organization and employees performances [12].

In research Harwini's get result that the government gives grants to empower them as listed on East Java Governor, Act No. 71/188/KPTS/013/2015, but in fact the financial support and commitment of the Government must be in vain without the role leadership [6]. Cooperative women need a strong leader to manage the Organization, such as how to manage the Fund on the right path. Grants should be used to increase the scale of its efforts, educating and training employees, however cases have been established on the use of grants for campaign prospective Regent.

Characteristics of the figurehead in a village decentralized era can adopt effective leadership Model American Management Association (AMA) which suggest that the lead using the head, feet, hands and hearts.

\section{1) Strategic Competency: Led By The Head}

The district head must be able to think the implementation of the planning and arrangements. So from that head should show leadership behavior as follows:

a). Creating a vision clearly relating to what will be achieved in a county development.

b). Developing strategy and planning of village development that is basically potentiate for the county's necessity.

c). Having the clear illustration about county development and community empowerment.

d). Understanding environmental development and correction entry suitability.

e). Having capability to determine various choice contrary and able to think logically and directive.

f). Opening minded and able to accept new ideas for county advantaging.

g). Able to solve the problem complexity and creativity in a county.

h). Able to take a decision flexibility

2) Performance management competency; Led By The Hand

The district head must be able to organize the efforts of organizations or an effective team to achieve the desired results. The behavior of leadership shown as follows:

a). Deciding the right way and activity goal clearly for staff or community group.

b). Deciding role and responsibility for each head.

c). Having ability to implement leadership style according to condition and own staff.

d). Having ability to take a role as trainer, empowering staff and community as well as taking delegation correctly.

e). Giving compliments that timely and appropriate corrective feedback.

f). Recognizing the work of people and giving them rewards for their achievements and improve your face.

g). Facing and increasing performance badly; and give priority to discipline when it is needed.

h). Having ability to solve crisis problem; identifying and solving a conflict. 
i). Giving a support for the staff, community organization or group.

j). Building cohesive teams of people working together toward a common goal.

$\mathrm{k})$. Leading a change, and include the community as well as minimizing opposite parties.

\section{3) Inspirational Competency: Led By The Heart}

The District head demand, energize and empower communities to strive for achieving the goal of shared through the effective communication of the vision, demonstrating a commitment to value and using the power of positive influence for the purpose of county construction. Leadership behavior is shown as follows:

a). Communicating a vision to the community attractively in order it will inspire them.

b). Increasing the openness, and communication interactively with various parties.

c). Having ability to understand others, such as value, aspiration, necessity, desire, and suitable with their moral value.

d). Showing the self-confidence, explicit but not aggressive.

e). Utilizing the positive power to influence negotiation process, involvement, way and sample. wise

f). Having ability in self-controlling and always being

g). Complying security, status and social necessity for the community.

h). Providing meaning and inspiring community about ideas and effort.

i). Creating high cultural achievement for the county advantaging.

\section{4) Character Competency: Led By Belief}

The district head is using the ethical responsibility to gain trust. The typical behavior of the leadership as follows:

- Having integrity;

- Upholding the values and principles that create a trust condition and integrity;

- Showing the courage to take difficult decisions in line with the ethical principles;

- Keeping a promise;

- Accepting accountability measures themselves and followers of;

- Being a decent example for others.

\section{CONCLUSION}

Based on the results of the concept analysis of village leaders figure that are characteristic of the district head formulated taking into account the task of the district head in decentralization era which includes governance, development and empowerment. Then it is adopting the model of effective leadership of the American Management Association (AMA) which includes; strategic competence, performance competence, inspirational competence and character competence.

\section{ACKNOWLEDGMENT}

The author would like to thank the dean of Faculty of Social Sciences and Law, Universitas Negeri Surabaya facilities for giving some results of the study conducted.

\section{REFERENCES}

[1] T. . C. Obiwuru, A. T. Okwu, V. O. Akpa, and I. A. Nwankwere, "Effects of Leadership Style on Organisational Performance: A Survey of Selected Small Scale Enterprises in Ikosi-Ketu Council Development Area of Lagos State, Nigeria," Aust. J. Bus. Manag. Res., vol. 1, no. 7, pp. 100-111, 2011.

[2] V. Khan, M. H. Hafeez, S. M. H. Rizvi, A. Hasnain, and A. Mariam, "Relationship of Leadership Styles, Employees Commitment and Organisation Performance (A Study on Customer Support Representatives)," Eur. J. Econ. Financ. Adm. Sci., vol. 49, pp. 134142,2012

[3] L. W. Fry, "Towards a Theory of Spiritual Leadership," Leadersh. $Q$., vol. 14, pp. 693-727, 2003.

[4] Sopiah, Perilaku Organisasi. Yogyakarta: Andi, 2008

[5] A. M. Thomas, Gurus on Leadership. London, UK: Thorogood Publishing Ltd, 2006.

[6] W. Harwini, "Influence of servant leadership on motivation, organization culture, organizational commitment, job involvement, organization citizenship behavior (OCB) and employee performance in women cooperative," Procedia - Soc. Behav. Sci., vol. 219, pp. $283-290,2016$

[7] B. Benkhoff, "Ignoring commitment is costly; new approaches establish the missing link between commitment and performance," Hum. Relations, vol. 50, no. 6, pp. 701-726, 1997.

[8] P. M. Podsakoff, "Transformational leader behavior and their effects on followers trust in leader,satisfaction, and organizational citizenship behaviors," Leadersh. Q., vol. 1, no. 1, 1990.

[9] G. M. Tehran, "The relationship between organizational citizenship behavior and performance," J. Acad. Res. Bus. Soc. Sci., vol. 3, no. 9, pp. 534-542, 2013.

[10] J. A. Le Pine, "The nature and dimensionality of organizational behavior: A critical review and meta analysis," J. Appl. Psychol., vol. 87, pp. 52-65, 2002.

[11] C. A. O'Reilly and J. Chatman, "Organizational commitment and psychological attachment; The effect of compliance,identification and internalization on pro-social behavior," J. Appl. Psychol., vol. 71, pp. 492-499, 1986.

[12] S. Wahaba, A. Rahmatb, M. S. Yusofc, and B. Mohamed, "Organization Performance and Leadership Style: Issues in Education Service," Procedia - Soc. Behav. Sci., vol. 224, pp. 593 598,2016 